\title{
Facial nerve damage following surgery for cerebellopontine angle tumours. Prevention and comprehensive treatment
}

\author{
Uszkodzenie nerwu twarzowego u chorych po operacjach guzów kq̨a mostowo- \\ -móżdżkowego. Zapobieganie i kompleksowe postępowanie terapeutyczne
}

Przemystaw Kunert, Beata Smolarek, Andrzej Marchel

Department of Neurosurgery, Medical University of Warsaw, Poland

Neurologia i Neurochirurgia Polska 2011; 45, 5: 480-488

\begin{abstract}
Facial nerve (CN VII) palsy or even its transient paresis causes physical disability but is also a psychosocial problem. Immediately after vestibular schwannoma removal, different degrees of CN VII paresis occur in $20-70 \%$ of patients. Facial nerve paresis is observed in $10-40 \%$ after surgery of cerebellopontine angle meningiomas. Postoperative facial nerve weakness significantly reduces or completely withdraws with time in the majority of cases. However, even if prognosis for CN VII regeneration is good, proper management is needed because of the potential for serious ophthalmic complications. In this paper, the authors raise the issue of perioperative prophylaxis and comprehensive treatment of postoperative paresis of CN VII. Prophylaxis and treatment of ophthalmic complications are discussed. Current trends in the treatment of intraoperative loss of facial nerve continuity, management of facial paresis with good prognosis and dealing with facial palsy with no spontaneous recovery are also described in the paper.
\end{abstract}

Key words: facial nerve, facial paralysis, vestibular schwannoma, meningioma, cerebellopontine angle tumour.

\section{Streszczenie}

Porażenie, a nawet przejściowy niedowład nerwu twarzowego, powoduje fizyczną niepełnosprawność, ale stanowi również problem psychosocjalny. Bezpośrednio po operacji osłoniaka nerwu przedsionkowego u 20-70\% chorych pojawia się różnego stopnia niedowład nerwu VII. W przypadku oponiaków okolicy kąta mostowo-móżdżkowego niedowład nerwu VII obserwuje się po operacji w $10-40 \%$ przypadków. U większości chorych pooperacyjny niedowład nerwu VII z czasem znacząco się zmniejsza lub całkowicie wycofuje. Niemniej nawet w przypadku dobrego rokowania co do regeneracji nerwu VII konieczne jest właściwe leczenie ze względu na możliwość wystąpienia poważnych powikłań ocznych. W niniejszej pracy autorzy poruszają zagadnienia okołooperacyjnej profilaktyki uszkodzenia nerwu VII oraz kompleksowego postępowania w przypadku wystąpienia niedowładu tego nerwu po operacji. Omówiono profilaktykę i leczenie powikłań ocznych porażenia nerwu VII. W pracy opisano także aktualne trendy postępowania w przypadku przerwania nerwu VII w czasie usuwania guza, strategie leczenia niedowładu rokującego samoistną regenerację oraz gdy czynność nerwu nie powraca.

Słowa kluczowe: nerw twarzowy, porażenie nerwu twarzowego, osłoniak nerwu przedsionkowego, oponiak, guz kąta mostowo-móżdżkowego.

Correspondence address: Przemysław Kunert, Katedra i Klinika Neurochirurgii, Warszawski Uniwersytet Medyczny, ul. Banacha 1 A, 02-097 Warszawa, fax + 482265836 53, e-mail: pkunert@wp.pl

Received: 25.01.2011; accepted: 4.05.2011 


\section{Introduction}

A palsy or even paresis of the facial nerve (CN VII) may occur at many stages in the treatment of cerebellopontine angle tumours and is a multidisciplinary problem. In the perioperative period, prophylaxis of CN VII damage and actions in case of $\mathrm{CN}$ VII disruption during tumour removal are very important. In later periods, strategies should be distinguished for treatment of palsy with the potential for spontaneous recovery, and when the nerve function is not recovered. From the moment of surgery, prophylaxis must be considered together with treatment for possible ophthalmic complications following $\mathrm{CN}$ VII paresis. Also, monitoring and treatment of delayed postoperative CN VII palsy, as well as palsy following radiosurgery with various delay, are important issues which seem to be sometimes overlooked.

\section{Facial nerve function following surgical and radiosurgical treatment of cerebellopontine angle tumours}

In centres specialising in surgical treatment of vestibular schwannomas, the chances for preservation of good CN VII function, i.e., grade I or II in the House-Brackmann grading system (HB, see Table 1) [1], are approximately $90 \%$ in late follow-up. The risk of its palsy (HB grade VI), on the other hand, is about 1.5\% [2]. Regardless of preserving anatomical continuity of CN VII, in about $20-70 \%$ of patients palsy of various degrees (HB grades II-VI) occurs immediately after surgical treatment of vestibular schwannomas, which in the majority of them significantly decreases or completely withdraws in time $[2,3]$. The risk of nerve damage increases in the case of larger tumours, and it is inversely proportional to the number of operations of that type per- formed at a given centre [4,5]. Despite recently published excellent results for preserving CN VII, when studying quality of life in 1,595 patients operated on for vestibular schwannomas via various approaches, as many as $45 \%$ of them were affected by paresis of CN VII, and in $72 \%$ of those cases, it was permanent [6]. Additionally, as many as $28 \%$ of all respondents described the weakness of facial muscles as significant. The issue of patients in whom continuity of CN VII was preserved during removal of vestibular schwannoma, yet its palsy is observed after the surgery, seems to be somewhat underestimated. The question is, in what ratio does a satisfactory reinnervation of facial muscles occur? In the series of Coca Pelaz et al., among 30 patients with palsy of CN VII despite preserved anatomical continuity, one year after surgery only in 5 (17\%) did a complete nerve recovery occur (HB grade I), while in $15(50 \%)$ the recovery results were unsatisfactory (HB grades IV-VI) [7].

The situation is similar with cerebellopontine angle meningiomas. In the group of 347 patients analysed by Nakamura et al., preservation of CN VII function of $\mathrm{HB}$ grade I after surgery ranged from $76 \%$ to $90 \%$, depending on the specific site of meningioma attachment to the pyramid [8]. In the material of $\mathrm{Wu}$ et al., anatomical preservation of the nerve was achieved in $97.5 \%$, and functional in $81 \%$ of the cases [9]. In cases where meningioma grows from the internal auditory meatus or fills it, even at the centres specialising in its treatment, the ratio of $\mathrm{CN}$ VII paresis is about $40 \%$, and its disruption, 20\% [10].

The issue of maintaining CN VII function also concerns patients after radiosurgical treatment, where the palsy may appear with various delay. That makes its diagnosis and sufficiently early therapeutic reaction difficult. In the meta-analysis in 2000 it was estimated that frequency of the complication following radiosurgery with the gamma knife for vestibular schwannomas was very

Table 1. House-Brackmann grading scale [1]

\begin{tabular}{|ll|}
\hline Grade & Definition \\
\hline I & Normal symmetrical function in all areas. \\
\hline II & $\begin{array}{l}\text { Slight weakness noticeable only on close inspection. Complete eye closure with minimal effort. } \\
\text { Slight asymmetry of smile with maximal effort. Synkinesis barely noticeable, contracture, or spasm absent. }\end{array}$ \\
\hline III & $\begin{array}{l}\text { Obvious weakness, but not disfiguring. May not be able to lift eyebrow. Complete eye closure and strong but } \\
\text { asymmetrical mouth movement with maximal effort. Obvious, but not disfiguring synkinesis, mass movement or spasm. }\end{array}$ \\
\hline IV & $\begin{array}{l}\text { Obvious disfiguring weakness. Inability to lift brow. Incomplete eye closure and asymmetry of mouth } \\
\text { with maximal effort. Severe synkinesis, mass movement, spasm. }\end{array}$ \\
\hline V & $\begin{array}{l}\text { Motion barely perceptible. Incomplete eye closure, slight movement corner mouth. Synkinesis, contracture, } \\
\text { and spasm usually absent. }\end{array}$ \\
\hline
\end{tabular}

Grade VI is considered as a total paralysis (no movement) of CN VII. 
similar to that following surgery. In both cases, good results (HB grades I-II) were achieved in $81 \%$ of patients. An unsatisfactory result ( $\mathrm{HB}$ grades V-VI) was observed in $4 \%$ of surgically and $6 \%$ of radiosurgically treated patients, respectively [11]. In more current estimations, the ratio of significant damage to $\mathrm{CN}$ VII following radiosurgery was about $4 \%[12]$.

\section{Consequences of facial nerve damage}

Palsy, or even temporal paresis of CN VII, results in physical disability, but is also a psychosocial issue $[6,13]$. Often, despite good results of cranial base tumour treatment and good oncological prognosis, in the patient's opinion the treatment results are not satisfactory due to deformation of the face. Low self-esteem may be a reason for feelings of disability, unsuccessful treatment and, in consequence, depression. On the other hand, objective disturbances in CN VII function may have permanent consequences. That concerns, particularly, ophthalmic complications in the form of conjunctivitis and corneal ulceration, and even loss of sight [14]. Following incorrect recovery of CN VII, synergic and autonomous synkinesis, mass movement and spasm may also occur [15].

\section{Perioperative prophylaxis of facial nerve damage}

Protection of the facial nerve begins already during surgery. Microneurosurgical operating methods and intraoperative neurophysiological monitoring increase the chances for functional preservation of the nerve [16]. Also important is an appropriate technique for microsurgical dissection of a tumour in the CN VII vicinity. Detailed description of operating techniques is not an objective of this publication; however, it must be mentioned that the priority is preserving delicate branches of the anterior inferior cerebellar artery supplying the nerve bundle and, if possible, the removal of a tumour while still preserving the CN VII arachnoid membrane. Samii particularly emphasised the need for avoiding stretching of the neural structures, avoiding use of coagulation in its vicinity, as well as a need for continuous irrigation of the operating area [17]. In cases when schwannomas are strongly attached to CN VII, it may be justified to dissect a tumour either in a layer not exceeding vestibular nerve perineurium or subcapsulary. The so-called 'tumour capsule', from the surgical point of view, should be consi- dered as the arachnoid mater, perineurium (a thin layer of connective tissue surrounding a tumour) and remains of nerve fibres of the vestibular nerve flattened around a tumour [18].

Steroids are commonly administered in the perioperative period, due to their alleged protective action [19], although even in treatment of CN VII paresis of Bell type, the role of steroids remained undetermined for a long time $[14,20]$. There were only a few studies conducted to answer the question of whether administering steroids increased preservation of CN VII function after surgery. In the retrospective study of Buchman et al., administering intraoperatively a single dose of dexamethasone did not influence the final result for CN VII function [21], whereas it was demonstrated in an animal model that damaged CN VII recovered faster and more effectively when a calcium channel blocker, nimodipine, was administered [22]. The first clinical studies of that subject seem to confirm the usefulness of vasoactive drugs (nimodipine together with hydroxyethyl starch solution) in the postoperative period [23]. A positive influence of that treatment was also demonstrated when it was introduced preventively on the day preceding surgery or intraoperatively, when neurophysiological symptoms of damage to CN VII function were recorded [24]. A possible mechanism of action may be improvement in microcirculation accelerating axons regrowth, improvement in remyelination and protection of neurones against degeneration. Reduction in calcium inflow to cells may also inhibit apoptosis [22-24].

Intraoperative EMG monitoring is one of the greatest achievements in prophylaxis of CN VII damage in the last 30 years [25]. Currently, it is widely used in surgery of cerebellopontine angle tumours. Particularly, during operation of vestibular schwannoma, electrical stimulation and continuous monitoring of spontaneous activity help to identify CN VII, and then to monitor its function [19]. In the series of Harner et al., the introduction of intraoperative neurophysiological monitoring doubled the rate of continuity preservation of CN VII (from $33 \%$ to $67 \%$ ) during removal of large schwannomas [26]. On the other hand, intraoperative overstimulation of CN VII must be avoided, as it is suspected that it may be one of the causes of postoperative paresis. Currently, it is thought that 'A trains' in an EMG record (that is, sinusoidal high-frequency waves of homogeneous appearance), lasting over 10 seconds, are the most reliable indicators of profound damage of CN VII during surgery [3]. 


\section{Prophylaxis and treatment of ophthalmic complications of facial nerve paresis}

Lagophthalmos is the most important component of facial muscle paresis, as it poses a risk of conjunctivitis, cornea ulceration, iritis, glaucoma, cataract, corneal opacity, endophthalmitis, and, in consequence, also of blindness. Prophylaxis of those complications is based mainly on regular and frequent moistening of the eye with artificial tears and/or bacteriostatic formulations (e.g., sulfacetamidum) during the day and using dexpanthenol gel in the night. Auxiliary use of a humidity chamber also yields good results [26]. It is attached to the skin around the orbit edges, protecting the conjunctiva and cornea against drying.

In cases of significant lagophthalmos it is important to restore complete closing of lids as early as possible, even when we expect spontaneous recovery of the nerve. Surgical treatments to improve closing of lids are divided into static and dynamic. Examples of the most often performed static procedures are implantation of a gold plate and lateral tarsorrhaphy, while dynamic procedures include transposition of the temporal muscle and a palpebral spring implant [27]. The latter, however, is not commonly used due to difficulties in the implantation itself and frequent complications [14]. A popular method is to load the upper lid by implanting a gold plate [28]. In the authors' centre, for the last few years that procedure has been used routinely in cases when lagophthalmos persists a few days after surgery. This allowed a significant reduction in the risk of serious ophthalmic complications. Advantages of earlier implantation, i.e., within 30 days of CN VII palsy, of a gold weight are also confirmed by other authors [29]. In the material of Harrisberg et al., in long-term observations following implantation of a gold weight into an upper lid, in $99 \%$ the integrity of the cornea was maintained, while in $10 \%$ of cases the plate had to be removed due to its migration, piercing the skin or excessive eyelid drop [30]. Less invasive modification of that method is sticking external plates to the upper lid (to our knowledge, they are not commercially available in Poland) [31]. The advantage of external plates is a possibility to change their weight as required and temporary removal for movement rehabilitation, when CN VII function returns. Other options include air injection into eyelids and injecting botulinum toxin into the upper lid. The action of the air lasts for a few days, while botulinum toxin persists for about 1.5 months [32,33]. A temporary correction of lower lid ectropion may be achieved by ap- plying 'Steri-Strip' plasters to it [34]. When palsy of the orbicular oculi muscle does not withdraw, a surgical correction of the eyelids is applied. Those treatments include lateral tarsorrhaphy, recession of the upper lid levator, lateral canthal sling and canthoplasty, which besides protecting the cornea also correct the cosmetic appearance of the face [35]. A dynamic way to reactivate lid function is transposition of part of the temporal muscle $[36,37]$. In advanced cases of corneal ulceration, resistant to pharmacological treatment, transplantation of amniotic membrane or cornea is performed [38].

\section{Treatment in case of facial nerve disruption during tumour removal}

In case of CN VII disruption during tumour removal, its end-to-end anastomosis must be attempted 'loco operationis'. Additionally, a benefit of simultaneous treatment is avoidance of additional surgical treatment and sacrificing other healthy motor nerves. There are cases, however, where direct end-to-end anastomosis is technically impossible. In such cases, a cable graft may be considered, for example, from the sural nerve [39]. When anastomosis of CN VII during the same surgery is not possible, extratemporal anastomosis, e.g., with the hypoglossal nerve, is recommended as soon as possible.

\section{Facial nerve paresis with good prognosis}

In case of $\mathrm{CN}$ VII paresis occurring after the surgery despite preserving its continuity, management includes waiting for spontaneous recovery of its function, supportive physiotherapy, as well as prevention and treatment of possible ophthalmic complications. Periodic clinical and electromyographic examinations are necessary, as satisfactory regeneration may not occur in all cases and a decision on more aggressive methods for face reanimation must be made on time.

\section{Physiotherapy in the treatment of facial nerve paresis}

To date, there have been no high-quality, randomized controlled trials assessing effectiveness of physiotherapy in reanimation of the paralysed face [40]. There are retrospective studies indicating the effectiveness of physical therapy in idiopathic CN VII paresis [41]. There 
are only a few publications on physiotherapy following surgery for cerebellopontine angle tumours and CN VII anastomosis and muscle grafts $[42,43]$. Despite the paucity of scientific evidence, physiotherapy is routinely prescribed while awaiting recovery or improvement in CN VII function. Active exercises of facial muscles play an important role, but it is emphasised that those attempts should not be made too early in case of CN VII palsy: first, because when there is no reinnervation, those exercises have no effect and may be frustrating for a patient; secondly, at the early stage of reinnervation, weakness in contraction of individual muscles promotes facial mass movement. That may further lead to persistent synkinesis, while the objective is to direct muscle re-education by controlling individual mimic movements from the very beginning [44]. Early movement rehabilitation after surgery for cerebellopontine angle tumour is effective when not a total paralysis, but only a paresis is diagnosed [45]. In further treatment, motor exercises performed regularly and individually by a patient at home are of fundamental importance for recovering satisfactory function of facial muscles. Interesting instructions for exercises recommended to patients following vestibular schwannoma surgery were presented by Samii and Matthies [46].

A promising therapy method based on the brain plasticity theory is re-education of facial muscles through individual exercises supported with EMG monitoring, with simultaneous visual and audio imaging of muscle work by a computer (biofeedback technique) $[45,47]$. The aim is to gain control of selective facial muscle movements. Brudny et al. achieved recovery of symmetric spontaneous facial expression in 33\% of patients after hypoglossalfacial anastomosis receiving auxiliary treatment with the biofeedback method [48]. In a prospective controlled study in 32 patients, Ross et al. observed a better improvement in patients with prolonged CN VII paresis treated with the 'biofeedback' method with EMG and in patients exercising in front of a mirror, versus the control group [49]. Individual exercises in front of a mirror do not require complex equipment and may be done at home.

Use of electrostimulation of the facial nerve remains controversial. To this day there is no unambiguous evidence of its effectiveness. The theory that electrostimulation helps to preserve muscles in a better condition until their reinnervation is not confirmed by scientific studies [44]. There are reports suggesting that it can accelerate CN VII regeneration and improve its final results [50]. Other studies, however, indicate that electrostimulation may even adversely affect reinnervation progress [51]. In a study on animals, better regeneration of the nerve was achieved with manual stimulation, while electrical stimulation provided no advantage [52]. On the other hand, it was found that in rats, combined treatment with electrostimulation of the nerve and systemic administration of testosterone accelerated CN VII regeneration after damage [53].

Comprehensive physiotherapeutic treatment of facial muscle palsy also includes therapeutic massage, warm compresses, lymphatic drainage and phototherapy (sollux lamp equipped with a blue filter). Physical therapy is generally contraindicated in patients with neoplasm. Nevertheless, there is no evidence that it increases the risk for re-growth of a benign cranial base tumour after its complete removal and thus it is used routinely [42]. Physiotherapy is not successful to the same extent in everybody. Zgorzalewicz and Łaksa, for example, noted that facial functions improvement during physiotherapy is slower and incomplete in patients of the age over 65 years and in patients with arterial hypertension, diabetics or with obesity [54]. Temporary correction of facial asymmetry and pulling of paralysed nerves by the healthy side may be achieved by sticking special plasters lifting the paralysed part of the face ('Kinesiotaping') [55].

\section{Treatment of delayed facial nerve palsy}

Delayed palsy is defined as deterioration of CN VII function not directly after surgery but some time later despite preservation of its continuity and function during removal of a tumour. When applying liberal criteria, that complication is observed in a wide range of $11 \%$ to $41 \%$, while when applying a strict precondition for deterioration, i.e., more than 3 days after surgery, frequency of that phenomenon approaches 5\% [56]. Up to now there is no specific prophylaxis management to avoid delayed CN VII palsy, especially as a cause of that phenomenon is not well known. Among others, vasospasm with secondary ischaemia of CN VII, nerve oedema in the area of the porus acusticus internus, nerve pulling due to cerebrospinal fluid flow and reactivation of viral infection are suspected $[4,56]$. However, effectiveness of preventive use of antiviral drugs has not yet been proven. There is also no scientific evidence for steroid treatment to reduce risk or improve treatment results [56]. Nevertheless, use of dexamethasone in the postoperative period as prophylaxis and extending that therapy to 2-3 weeks after surgery in case of delayed CN VII palsy is a common practice [4]. Fortunately, prognosis 
in the case of this complication is usually good. In the series of Grant et al., improvement to HB grade I or II was found in $80 \%$ of patients after 3 months and $93 \%$ after a year, while factors leading to poor results of the treatment were extent of deterioration (exceeding three HB grades) and larger diameter of a tumour [56]. It is important to forewarn the patient about a possibility of the aforementioned complication as it can appear after discharge from the hospital.

\section{Management in case of no recovery of facial nerve function}

If no spontaneous reanimation of facial muscles is observed within several months after surgery, despite CN VII continuity preservation, an anastomosis of CN VII with another nerve should be considered [57]. A meta-analysis of results of hypoglossal-facial anastomosis, published in 2007 by Yetiser and Karapinar, showed higher effectiveness in the case of operations performed within 12 months of the damage of CN VII [58]. After that time, the role of nerve anastomosis is gradually taken over by plastic surgery.

\section{Extratemporal anastomosis of facial nerve}

The idea of CN VII anastomosis with other nerves reaches back to the end of the $1^{\text {th }}$ century. Currently, the hypoglossal nerve is most often used for that purpose. Typical hypoglossal-facial anastomosis consists of cutting the healthy hypoglossal nerve and connecting its proximal stump end-to-end with the distal stump of CN VII, which is cut off at the stylomastoid foramen. This method is acknowledged as being relatively efficient but results in deterioration of the appearance and function of the tongue [58]. One way to minimise hemitongue atrophy is to perform additional anastomosis of the ansa cervicalis with the hypoglossal nerve [59]. Currently, effectiveness of that method is questioned, and a possible reason for low effectiveness may be the ansa cervicalis having a small number of axons compared to the hypoglossal nerve [60].

For the last 20 years, methods for CN VII anastomosis partly sparing the hypoglossal nerve have been rapidly developing. It is worth mentioning a few of these methods, such as the technique of longitudinal division of the hypoglossal nerve [61], 'side-to-end' technique with a cable graft ('May technique') [62] and direct end-to- side anastomosis with rerouting of the mastoid portion of CN VII ('Darrouzet technique') [63].

Another technique is facial-facial anastomosis, making possible reinnervation from the healthy contralateral CN VII $[64,65]$. An advantage of that method is the possibility of partial recovery of spontaneous facial mimics. Adversely, it requires 2-3 relatively long grafts from the sural nerve between connected distal branches of both facial nerves, that is, at least 4-6 connection sites, and that decreases the chances for good reinnervation of paralysed muscles. Although donors are CN VII branches on the healthy side, deterioration in facial functions on that side is usually small and temporary [66]. A particular advantage of that procedure is the fact that slight denervation of the healthy side of the face reduces facial asymmetry and muscle dragging to the non-affected side.

An interesting concept is the 'baby-sitter' technique, based on combining hypoglossal-facial anastomosis with facial-facial anastomosis. The idea is to use the high efficiency of hypoglossal-facial anastomosis in reinnervation of facial muscles and, at the same time, to offer a chance of recovering emotional function $[67,68]$. With a technique sparing a part of the hypoglossal nerve, satisfactory reanimation of facial muscles may be achieved with minimum damage to function of the tongue and the non-affected side of the face. Nevertheless, 'facial-facial' anastomosis and the 'baby-sitter' technique are used rather rarely due to the complexity of the procedures and uncertain effects.

\section{Plastic surgery}

Kukwa et al. suggest performing plastic surgery of facial muscles together with CN VII anastomosis. The aim of that procedure is to achieve the closing of lids as soon as possible, without waiting a few months for reinnervation of paralysed muscles. Using the temporal muscle fibres and its fascia, as well as the oblique layer of the masseter muscle, dynamic reconstruction of eyelids and the mouth corner can be performed, respectively. The described procedure may be simultaneously extended with plastic surgery of the facial skin ('face-lifting') $[36,59]$. The fact that the complex treatment can be performed during one procedure is an additional advantage. On the other hand, recovery of the paralysed muscles' function may overlap the results of plastic surgery in a way difficult to foresee. Thus it is also rational to decide about plastic surgery when the final result of nerve anastomo- 
sis is achieved - particularly as we have at our disposal less invasive, 'passive' methods for temporary protection of the face, such as 'kinesiotaping' or loading of the upper lid.

Selected techniques in cases of prolonged CN VII palsy are muscle transpositions and free muscle flap grafts. For transposition, fibres of the temporal muscles are used, or, less often, of the masseter muscle or the platysma $[37,59]$. To perform a free graft, portions of the gracilis, serratus anterior, latissimus dorsi, pectoralis minor or rectus abdominis muscle are harvested [69,70]. In the FFMT technique (free functional muscle transfer), a free muscle flap is fixed to the zygomatic arch and in the mouth corner area, while the neurovascular bundle is anastomosed with superficial temporal vessels and with the maxillary nerve [69].

Muscle transpositions and grafts are dynamic techniques. Static procedures include Z-plasty of the mouth corner and wedge resection of the lower lip [15]. Other options include injections of botulinum toxin into muscles on the non-affected side of the face, to reduce facial asymmetry during rest and mimic movements [71].

\section{Conclusions}

Planning of CN VII palsy treatment must be individually tailored to the patient's expectations. Some patients prefer to accept paresis as they have no motivation for prolonged rehabilitation, as well as reconstructive surgery. On the other hand, in persons with low self-esteem, women and young people, facial asymmetry and dysfunction usually pose a significant problem [72]. Very important is to make a patient aware of realistic expectations in cases of surgical treatment of the paralysed face and his/her close cooperation throughout the treatment process. In performing surgical or radiosurgical treatment of cranial base tumours, one has to be aware of CN VII palsy occurring due to the treatment. That also concerns knowledge of currently available facial reanimation methods. Apart from mastering neurosurgical procedures

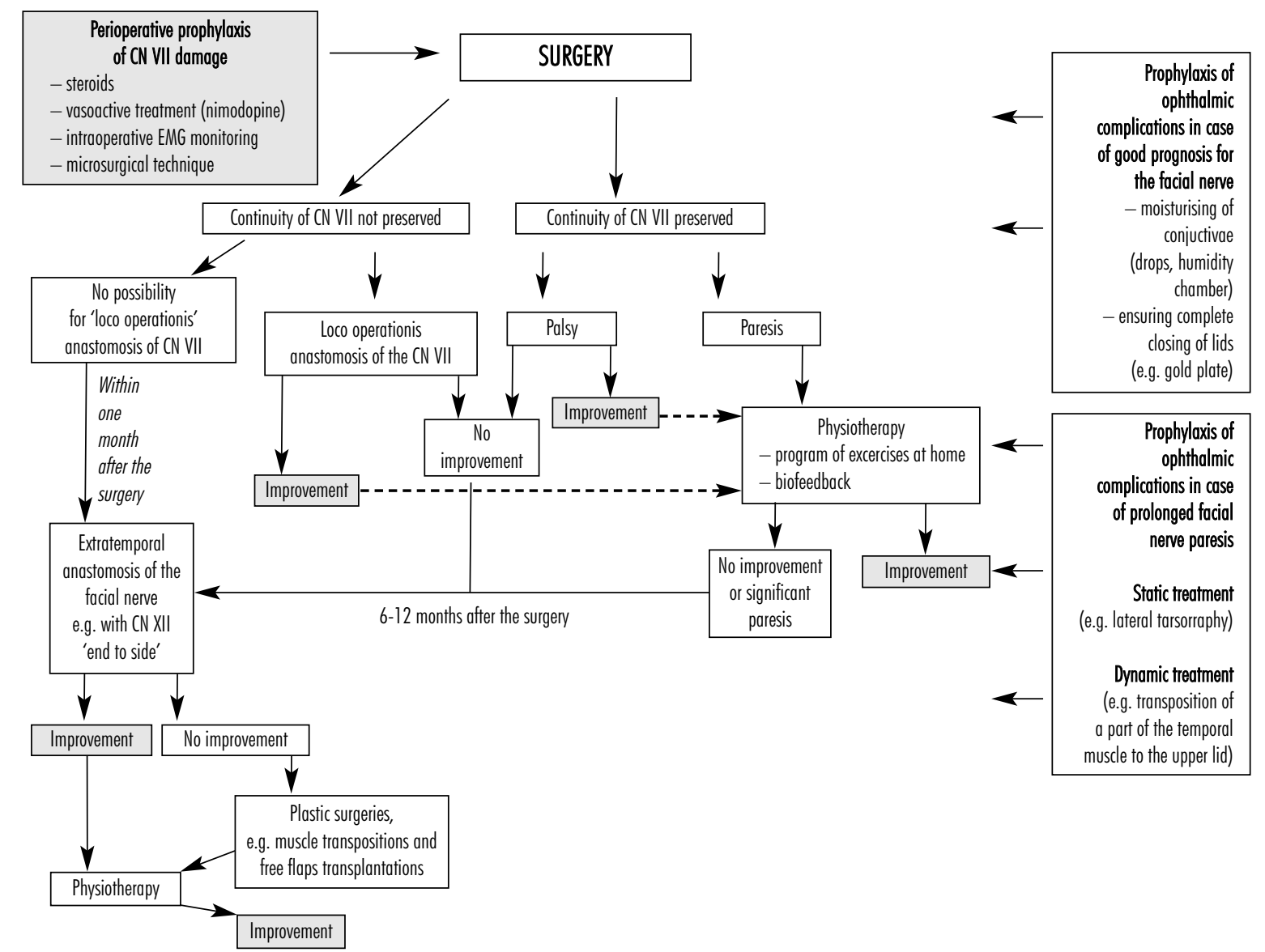

Fig. 1. Possible algorithm for prevention and comprehensive treatment of facial palsy after surgery 
such as nerve anastomosis, also cooperation with physiotherapists and ophthalmic or plastic surgery specialists is required, to optimise final treatment results (Fig. 1).

\section{Disclosure}

The authors report no conflict of interest.

\section{References}

1. House J.W., Brackmann D.E. Facial nerve grading system. Otolaryngol Head Neck Surg 1985; 93: 146-147.

2. Sampath P., Holliday M.J., Brem H., et al. Facial nerve injury in acoustic neuroma (vestibular schwannoma) surgery: etiology and prevention. J Neurosurg 1997; 87: 60-66.

3. Prell J., Rampp S., Romstock J., et al. Train time as a quantitative electromyographic parameter for facial nerve function in patients undergoing surgery for vestibular schwannoma. $J$ Neurosurg 2007; 106: 826-832.

4. Sampath P., Long D.M. Acoustic neuroma. In: Winn H.R. [eds.]. Youmans neurological surgery. Fifth edition. Saunders, Philadelphia 2004, pp. 1147-1168.

5. Hastan D., Vandenbroucke J.P., van der Mey A.G. A meta-analysis of surgical treatment for vestibular schwannoma: is hospital volume related to preservation of facial function? Otol Neurotol 2009; 30: 975-980.

6. Ryzenman J.M., Pensak M.L., Tew J.M. Jr. Facial paralysis and surgical rehabilitation: a quality of life analysis in a cohort of 1,595 patients after acoustic neuroma surgery. Otol Neurotol 2005; 26: 516-521.

7. Coca Pelaz A., Fernández Lisa C., Gómez J., et al. Complete facial palsy following surgery for acoustic nerve neurinoma: evolution and associated ophthalmological complications. Acta Otorrinolaringol Esp 2008; 59: 223-227.

8. Nakamura M., Roser F., Dormiani M., et al. Facial and cochlear nerve function after surgery of cerebellopontine angle meningiomas. Neurosurgery 2005; 57: 77-90.

9. Wu Z.B., Yu C.J., Guan S.S. Posterior petrous meningiomas: 82 cases. $J$ Neurosurg 2005; 102: 284-289.

10. Roser F., Nakamura M., Dormiani M., et al. Meningiomas of the cerebellopontine angle with extension into the internal auditory canal. J Neurosurg 2005; 102: 17-23.

11. Kaylie D.M., Horgan M.J., Delashaw J.B., et al. A meta-analysis comparing outcomes of microsurgery and gamma knife radiosurgery. Laryngoscope 2000; 110: 1850-1856.

12. Yang I., Sughrue M.E., Han S.J., et al. Facial nerve preservation after vestibular schwannoma gamma knife radiosurgery. J Neurooncol 2009; 93: 41-48.

13. Bradbury E.T., Simons W., Sanders R. Psychological and social factors in reconstructive surgery for hemi-facial palsy. $J$ Plast Reconstr Aesthet Surg 2006; 59: 272-278.

14. Rahman I., Sadiq S.A. Ophthalmic management of facial nerve palsy: a review. Surv Ophthalmol 2007; 52: 121-144.

15. Kukwa A., Pietniczka M. Rekonstrukcja porażonej twarzy. Gazeta Stomatologiczna 1996; 3: 24-25.

16. Koerbel A., Gharabaghi A., Safavi-Abbasi S., et al. Evolution of vestibular schwannoma surgery: the long journey to current suc- cess. Neurosurg Focus 2005; 18: e10. [cited December 22, 2010]; http://thejns.org/doi/pdfplus/10.3171/foc.2005.18.4.11.

17. Samii M., Gerganov V., Samii A. Improved preservation of hearing and facial nerve function in vestibular schwannoma surgery via the retrosigmoid approach in a series of 200 patients. J Neurosurg 2006; 105: 527-535.

18. Sasaki T., Shono T., Hashiguchi K., et al. Histological considerations of the cleavage plane for preservation of facial and cochlear nerve functions in vestibular schwannoma surgery. $J$ Neurosurg 2009; 110: 648-655.

19. Youssef A.S., Downes A.E. Intraoperative neurophysiological monitoring in vestibular schwannoma surgery: advances and clinical implications. Neurosurg Focus 2009; 27: E9. [cited November 14, 2010]; http://thejns.org/doi/pdf/10.3171/2009.8.FOCUS09144.

20. Salinas R.A., Alvarez G., Daly F., et al. Corticosteroids for Bell's palsy (idiopathic facial paralysis). Cochrane Database Syst Rev 2010; 17: CD001942.

21. Buchman C.A., Fucci M.J., Slattery W.H., et al. Intraoperative corticosteroids in acoustic tumor surgery. Am J Otol 1999; 20: 386-389.

22. Angelov D.N., Neiss W.F., Streppel M., et al. Nimodipine accelerates axonal sprouting after surgical repair of rat facial nerve. J Neurosci 1996; 16: 1041-1048.

23. Strauss C., Romstöck J., Fahlbusch R., et al. Preservation of facial nerve function after postoperative vasoactive treatment in vestibular schwannoma surgery. Neurosurgery 2006; 59: 577-584.

24. Scheller C., Richter H.P., Engelhardt M. The influence of prophylactic vasoactive treatment on cochlear and facial nerve functions after vestibular schwannoma surgery: a prospective and open-label randomized pilot study. Neurosurgery 2007; 61: 92-97.

25. Delgado T.E., Bucheit W.A., Rosenholtz H.R., et al. Intraoperative monitoring of facial muscle evoked responses obtained by intracranial stimulation of the facial nerve: a more accurate technique for facial nerve dissection. Neurosurgery 1979; 4: 418-421.

26. Cortese D., Capp L., McKinley S. Moisture chamber versus lubrication for the prevention of corneal epithelial breakdown. Am J Crit Care 1995; 4: 425-428.

27. Bergeron C.M., Moe K.S. The evaluation and treatment of upper eyelid paralysis. Facial Plast Surg 2008; 24: 220-230.

28. El Shazly M., Guindi S. Static management of lagophthalmos following facial nerve paralysis using standardized weights. Rev Laryngol Otol Rhinol (Bord) 2008; 129: 263-266.

29. Snyder M.C., Johnson P.J., Moore G.F., et al. Early versus late gold weight implantation for rehabilitation of the paralyzed eyelid. Laryngoscope 2001; 111: 2109-2113.

30. Harrisberg B.P., Singh R.P., Croxson G.R., et al. Long-term outcome of gold eyelid weights in patients with facial nerve palsy. Otol Neurotol 2001; 22: 397-400.

31. Zwick O.M, Seiff S.R. Supportive care of facial nerve palsy with temporary external eyelid weights. Optometry 2006; 77: 340-342.

32. Prell J., Rampp S., Rachinger J., et al. Botulinum toxin for temporary corneal protection after surgery for vestibular schwannoma. J Neurosurg 2011; 114: 426-431.

33. Zlotnik E., Smeyanovich A., Tyappo E. Method of eyelid closure in facial nerve paralysis. Technical note. J Neurosurg 1982; 57: 722-723.

34. Schrom T., Habermann A. Temporary ectropion therapy by adhesive taping: a case study. Head Face Med 2008; 4: 12. 
35. Sadiq S.A., Downes R.N. A clinical algorithm for the management of facial nerve palsy from an oculoplastic perspective. Eye (Lond) 1998; 12: 219-223.

36. Kukwa A., Pietniczka M. Rekonstrukcja porażonej twarzy. Gazeta Stomatologiczna 1997; 1: 18-19.

37. Frey M., Giovanoli P., Tzou C.H., et al. Dynamic reconstruction of eye closure by muscle transposition or functional muscle transplantation in facial palsy. Plast Reconstr Surg 2004; 114: 865-875.

38. Gicquel J.J., Bejjani R.A., Ellies P., et al. Amniotic membrane transplantation in severe bacterial keratitis. Cornea 2007; 26: 27-33.

39. Samii M. Facial nerve grafting in acoustic neurinoma. Clin Plast Surg 1984; 11: 221-225.

40. Teixeira L.J., Soares B.G., Vieira V.P., et al. Physical therapy for Bell s palsy (idiopathic facial paralysis). Cochrane Database Syst Rev 2008; 16: CD006283.

41. Lindsay R.W., Robinson M., Hadlock T.A. Comprehensive facial rehabilitation improves function in people with facial paralysis: a 5-year experience at the Massachusetts Eye and Ear Infirmary. Phys Ther 2010; 90: 391-397.

42. Wilson C.M., Ronan S.L. Rehabilitation postfacial reanimation surgery after removal of acoustic neuroma: a case study. $J$ Neurol Phys Ther 2010; 34: 41-49.

43. Barbara M., Monini S., Buffoni A., et al. Early rehabilitation of facial nerve deficit after acoustic neuroma surgery. Acta Otolaryngol 2003; 123: 932-935.

44. Novak C.B. Rehabilitation strategies for facial nerve injuries. Semin Plast Surg 2004; 18: 47-52.

45. Vanswearingen J. Facial rehabilitation: a neuromuscular reeducation, patient-centered approach. Facial Plast Surg 2008; 24: 250-259.

46. Samii M., Matthies C. Management of 1000 vestibular schwannomas (acoustic neuromas): the facial nerve-preservation and restitution of function. Neurosurgery 1997; 40: 684-695.

47. Cronin G.W., Steenerson R.L. The effectiveness of neuromuscular facial retraining combined with electromyography in facial paralysis rehabilitation. Otolaryngol Head Neck Surg 2003; 128: 534-538.

48. Brudny J., Hammerschlag P.E., Cohen N.L., et al. Electromyographic rehabilitation of facial function and introduction of a facial paralysis grading scale for hypoglossal-facial nerve anastomosis. Laryngoscope 1988; 98: 405-410.

49. Ross B., Nedzelski J.M., McLean J.A. Efficacy of feedback training in long-standing facial nerve paresis. Laryngoscope 1991; 101: 744-750

50. Targan R.S., Alon G., Kay S.L. Effect of long-term electrical stimulation on motor recovery and improvement of clinical residuals in patients with unresolved facial nerve palsy. Otolaryngol Head Neck Surg 2000; 122: 246-252.

51. Sinis N., Horn F., Genchev B., et al. Electrical stimulation of paralyzed vibrissal muscles reduces endplate reinnervation and does not promote motor recovery after facial nerve repair in rats. Ann Anat 2009; 191: 356-370.

52. Skouras E., Merkel D., Grosheva M., et al. Manual stimulation, but not acute electrical stimulation prior to reconstructive surgery, improves functional recovery after facial nerve injury in rats. Restor Neurol Neurosci 2009; 27: 237-251.

53. Sharma N., Moeller C.W., Marzo S.J., et al. Combinatorial treatments enhance recovery following facial nerve crush. Laryngoscope 2010; 120: 1523-1530.
54. Zgorzalewicz M., Łaksa B. Physical therapy in peripheral facial paresis. Neurol Neurochir Pol 2001; 35 (Suppl 4): 111-124.

55. Hałas I., Senderek T., Krupa L. The use of kinesiotaping in improvement of face mobility in patient after facial nerve reconstruction. Fizjoterapia Polska 2005; 5: 272-276.

56. Grant G.A., Rostomily R.R., Kim D.K., et al. Delayed facial palsy after resection of vestibular schwannoma. J Neurosurg 2002; 97: 93-96.

57. Falcioni M., Taibah A., Russo A., et al. Facial nerve grafting. Otol Neurotol 2003; 24: 486-489.

58. Yetiser S., Karapinar U. Hypoglossal-facial nerve anastomosis: a meta-analytic study. Ann Otol Rhinol Laryngol 2007; 116: 542-549.

59. Kukwa A., Marchel A., Pietniczka M., et al. Reanimation of the face after facial nerve palsy resulting from resection of a cerebellopontine angle tumour. BrJ Neurosurg 1994; 8: 327-332.

60. Vacher C., Dauge M.C. Morphometric study of the cervical course of the hypoglossal nerve and its application to hypoglossal facial anastomosis. Surg Radiol Anat 2004; 26: 86-90.

61. Arai H., Sato K., Yanai A. Hemihypoglossal-facial nerve anastomosis in treating unilateral facial palsy after acoustic neurinoma resection. J Neurosurg 1995; 82: 51-54.

62. May M., Sobol S.M., Meester S.J. Hypoglossal-facial nerve interpositional-jump graft for facial reanimation without tongue atrophy. Otolaryngol Head Neck Surg 1991; 104: 818-825.

63. Darrouzet V., Guerin J., Bébéar J. New technique of side-to-end hypoglossal-facial nerve attachment with translocation of the infratemporal facial nerve. J Neurosurg 1999; 90: 27-34.

64. Anderl H. Cross-facial nerve transplant. Clin Plast Surg 1979; 6: 433-449.

65. Radek A. Zespolenie twarzowo-twarzowe: nowa możliwość w leczeniu uszkodzeń nerwu twarzowego. Neurol Neurochir Pol 1987; 21: 552-554.

66. Cooper T.M., McMahon B., Lex C., et al. Cross-facial nerve grafting for facial reanimation: effect on normal hemiface motion. J Reconstr Microsurg 1996; 12: 99-103.

67. Terzis J.K. 'Babysitters': an exciting new concept in facial reanimation. In: Castro D. [ed.]. Facial Nerve. Kugler \& Ghedini, Berkeley 1990, p. 525.

68. Yoleri L., Songür E., Mavioğlu H., et al. Cross-facial nerve grafting as an adjunct to hypoglossal-facial nerve crossover in reanimation of early facial paralysis: clinical and electrophysiological evaluation. Ann Plast Surg 2001; 46: 301-307.

69. Krishnan K.G., Schackert G., Seifert V. Outcomes of microneurovascular facial reanimation using masseteric innervation in patients with long-standing facial palsy resulting from cured brainstem lesions. Neurosurgery 2010; 67: 663-674.

70. Terzis J.K., Noah M.E. Analysis of 100 cases of free-muscle transplantation for facial paralysis. Plast Reconstr Surg 1997; 99: 19051921.

71. de Maio M., Bento R.F. Botulinum toxin in facial palsy: an effective treatment for contralateral hyperkinesis. Plast Reconstr Surg 2007; 120: 917-927.

72. Cross T., Sheard C.E., Garrud P., et al. Impact of facial paralysis on patients with acoustic neuroma. Laryngoscope 2000; 110: 1539-1542. 